\section{Reclaimed Wastewater for Irrigation of Citrus in Florida}

\author{
Frederick S. Davies and \\ Michael A. Maurer
}

Additional index words. Citrus paradisi, fertigation, nutrition

Summary. Reclaimed municipal wastewater has been used to irrigate young and mature sweet orange and grapefruit trees in Florida. In the central ridge area of Flori$\mathrm{da}$, trees receiving reclaimed wastewater had greater yields and improved tree vigor compared to trees receiving wellwater. The high level of reclaimed wastewater applied $(2.54 \mathrm{~cm} /$ week $)$, however, decreased fruit total soluble solids, acids, and their ratio. In contrast, tree vigor and fruit quality were not different for mature grapefruit trees growing in the coastal, flatwoods area of Florida, which received reclaimed wastewater or canal water. Yields, however, were higher for the reclaimed wastewater treatments in one season, but the effect was variable. No adverse effects of applying high levels of reclaimed wastewater were noted at either site. The use of reclaimed wastewater for citrus irrigation has potential benefits for Florida citrus growers in the future.

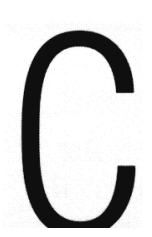

itrus is the most economically important fruit crop grown in Florida, with $>300,000$ ha and annual production of 6.8 million tons in 1990 (Florida Dept. of Agr., 1990). Citrus trees require significant amounts of irrigation to achieve optimum yields (Koo, 1963). In 1992, $34 \%$ of the available agricultural water in Florida was used to irrigate citrus (Smajstrla et al., 1992).

Horticultural Sciences Department, University of Florida, P.O. Box 110690, Gainesville, FL 32611

The research at Vero Beach was funded by the St. Johns River Water Management District and Indian River County.
With increasing demand for water from both the agricultural and urban sectors, water use for agriculture has become tightly regulated by Florida's water management districts. At the same time, tremendous increases in urbanization, particularly in coastal areas, have increased significantly the need for efficient and environmentally safe wastewater disposal. As a result, the Dept. of Environmental Regulation (DER) has tightened restrictions on discharge of municipal wastewater into surface waters. Therefore, a logical solution to these dilemmas is to reclaim treated municipal wastewater and use it for agricultural irrigation and groundwater recharge. Reclaimed municipal water has been used for irrigation of crops, pastures, and golf courses for many years in Florida, but only recently for citrus (Overman et al., 1987).

Several projects are currently underway in Florida involving use of reclaimed water for citrus irrigation. The largest and longest-established is the Conserv II/Southwest Orange County Water Reclamation Project. The project, which was initiated in 1986, provides $>95$ million liters/day of tertiary-treated municipal wastewater from the Orlando, Fla., area to agricultural sites, including 2800 ha of citrus in Orange County (McMahon et al., 1989) The treatment facility has the capacity to produce 190 million liters/day for irrigation of up to 6000 ha of citrus and also possesses large storage tanks to regulate the supply of water.

The soils in the Orlando (ridge) area are coarse sands with rapid infiltration characteristics that are ideal for efficient disposal of large quantities of reclaimed water. Citrus trees growing on these deep sands have extensive root systems, sometimes to depths of $5 \mathrm{~m}$, and yields as high as 80 to $100 \mathrm{t} \cdot \mathrm{ha}^{-1}$. Unfortunately, freezes in the 1980s severely damaged or killed $>100,000$ ha of citrus in Florida, particularly in the ridge area. The availability of largequantities of reclaimed water is also of potential benefit to citrus growers in this region because microsprinkler irrigation is an effective method of freeze protection, especially for young trees (Davies and Jackson, 1985).

The Conserv II project provides citrus growers with a long-term source of water (20-year contract) to be used for irrigation of young and mature citrus trees. Water is provided free, although growers must absorb costs associated with connection to the system and purchase of water meters. Growers have the option of refusing water 4 weeks per year, but only 2 weeks consecutively. Water that is not applied to groves-for example, during high rainfall-isdiverted to rapid infiltration basins (RIBs), where it percolates through the sand and eventually reaches the aquifer. Growers also may request double the allotted amount of water, but under the same restrictions as for water refusal.

Water quality is regulated very strictly. The water may not have detectable levels of fecal coliforms or viruses and must have $<30 \mathrm{mg}$.liter ${ }^{-1}$ biochemical oxygen demand (BOD) and $5 \mathrm{mg} \cdot \mathrm{liter}^{-1}$ total 
suspended solids (TSS). Reclaimed wastewater must be transported along different pipes than potable water and water outlets must be marked clearly as "reclaimed water." Reclaimed wastewater may not be applied via overhead irrigation to fruit destined for the fresh market (McMahon et al., 1989).

Other smaller reclaimed water facilities are located in Pasco County (west coast) (Servis, 1991) and Okeechobee County (east coast) and involve primarily individual growers and local treatment facilities. Recently, there has been great interest in the use of reclaimed wastewater in the Indian River flatwoods (east coast) area of Florida, which produced $>2$ million tons of citrus of citrus in 1989-90 (Florida Dept, of Agr., 1990). This area has considerably different soil types than those in the ridge area. Soils are extremely variable in texture, $\mathrm{pH}$, and structure. Most soils in the area are sands underlain by a hardpan or other impervious layer. In addition, the water table is usually very near the surface; thus, rooting depth is usually within $60 \mathrm{~cm}$ of the soil surface and yields are in the range of 50 to 60 t.ha $a^{-1}$. Therefore, citrus trees are grown on raised beds to facilitate drainage and promote adequate root growth.

Due to the great differences in soil and drainage characteristics between the ridge and flatwoods areas, a separate reclaimed wastewater study for the Indian River area was begun in 1989. Growers in the region are concerned about excessive irrigation and high salinity levels adversely affecting fruit yields and quality. This study is being conducted on a 12-ha site adjacent to the Vero Beach municipal wastewater treatment facility, which is owned by Indian River County. The project is funded by the county and St. John's River Water Management District. This paper discusses the effects of reclaimed municipal wastewater on growth and development, yields, and fruit quality of citrus growing on the ridge (Conserv II) and Indian River (Vero Beach) areas of Florida. Also discussed is how high levels of reclaimed wastewater affect soil oxygen and nutrient levels at the Vero Beach site.

Composition of reclaimed wastewater

Composition of reclaimed municipal wastewater varies considerably with location and season and is representative of the industrial and population base of the area. Many people believe that all reclaimed water is high in heavy metals such as cadmium, zinc, lead, nickel, and mercury, all of which are potentially hazardous to humans, This is only the case, however, for water from regions with heavy industry. In contrast, water from the Conserv II and Vero Beach facilities is low in heavy metals, reflecting the urban nature and lack of heavy industry in these areas (Table 1). Moreover, special industrial waste pretreatment programs have been developed in the Orlando
Table 1. Composition of reclaimed municipal wastewater for the Conserv II and Vero Beach treatment facilities.

\begin{tabular}{|c|c|c|}
\hline Chracteristic & Conserv $\|^{2}$ & Vero Beachy \\
\hline $\mathrm{pH}$ & 7.0 & 7.0 \\
\hline BOD (mg.liter $\left.{ }^{-1}\right)$ & 2.7 & 2.8 \\
\hline $\begin{array}{l}\text { Chemical oxygen } \\
\left.\text { demand (mg.liter }{ }^{-1}\right)\end{array}$ & 24.3 & 19.0 \\
\hline ECW ( $\mu \mathrm{mhos} / \mathrm{cm})$ & 668.3 & 900.0 \\
\hline $\begin{array}{l}\text { Total suspended } \\
\text { solids (mg.liter }{ }^{-1} \text { ) }\end{array}$ & 3.2 & 1.0 \\
\hline Bicarbonate (\%) & 97.2 & 80.5 \\
\hline
\end{tabular}

\begin{tabular}{lll} 
Elements & \multicolumn{2}{c}{ mg.liter $^{-1}$} \\
Boron & 0.18 & 0.45 \\
Calcium & 39.0 & 41.7 \\
Chloride & 79.1 & 176.0 \\
Copper & 0.017 & 0.026 \\
Iron & 0.09 & 0.032 \\
Magnesium & 9.0 & 22.9 \\
Manganese & 0.015 & Trace \\
Nitrogen & 10.1 & 10.2 \\
Nitrate & 8.2 & 8.6 \\
Phosphorus & 5.4 & 7.1 \\
Potassium & 11.5 & 15.9 \\
Sodium & 62.8 & 165.0 \\
Sulfates & 43.6 & 63.0 \\
Zinc & 0.067 & 0.047
\end{tabular}

${ }^{2}$ Average of 24 monthly samples (Koo and Zekri, 1989).

YRepresentative monthly sample (Maurer, unpublished data).

area. The water at both sites is quite similar in most characteristics, with the exception of significantly higher sodium, chloride, magnesium, and boron levels at the Vero Beach facility. After 6 years at Conserv II and 1.5 years at Vero Beach, however, no adverse effects on tree growth and development or yields have been observed related to elevated levels of these elements.

Reclaimed water also provides nutrients that have not been removed in the treatment process that may have beneficial effects on tree growth and yields. These nutrients are present at low levels; however, reclaimed wastewater is generally applied at high rates (2.5 to $3.8 \mathrm{~cm} /$ week) in order to dispose of as much water as possible per unit of land area. Therefore, levels of nitrogen, phosphorus, and potassium are appreciable, and may indicate lower levels of fertilizer to be applied (Ko0 and Zekri, 1989). For example, $\approx 80 \mathrm{~kg}$ of nitrogen is applied per year in $152 \mathrm{~cm}$ of water at the Vero Beach site. This is about $65 \%$ of the nitrogen needed to produce a fresh grapefruit crop in the Indian River area. Considerable amounts of phosphorus, and especially potassium, also are provided by the reclaimed water at both sites. In fact, high levels of potassium are a concern, because they may adversely affect fruit quality by increasing peel thickness to unacceptable levels.

Of major interest to consumers and marketing groups are the levels of bacteriaand viruses in the reclaimed wastewater. Levels of enteric viruses range from 3 to 480 most-probable infectious units/liter at the influx side of the Vero Beach plant, but they are consistently zero at the output side (S. Farrah, Dept. of Microbiology, Univ. of Florida, unpublished data). Similarly, no enteric viruses have been found at the Conserv II site over the 6year period of the study. Moreover, studies by the State Dept. of Health in Florida suggest that, even if fruit are dipped directly into untreated water, no viruses penetrate the peel into the fruit pulp or juice. More important, when fruit were run through packinghouse procedures no viruses were found, even on the peel (R. Lewis, State Dept. of Health, unpublished data). No viruses have been isolated from the peel of fruit collected from the Vero Beach site during the past 2 years (data not shown). In addition, fecal coliform levels are closely monitored and have been consistently less than 1 unit/ liter for both sites. Therefore, the probability of contamination of fruit by viruses or bacteria is extremely small. Further, enteric viruses are shortlived in the soil and are not taken up by plants ( $\mathrm{S}$. Farrah, personal communication). One potential

Table 2. Effects of reclaimed wastewater and wellwater on fruit quality of mature 'Hamlin' orange trees at Orlando, Fla., 1987-89.

\begin{tabular}{lllll}
\hline & & \multicolumn{3}{c}{ Year } \\
\cline { 4 - 5 } Measurement & Treatment & $\mathbf{1 9 8 7}$ & $\mathbf{1 9 8 8}$ & $\mathbf{1 9 8 9}$ \\
\hline No. samples & Wellwater & 1 & 8 & 9 \\
& Conserv II & 5 & 5 & 7 \\
Juice (\%) & Wellwater & 60.1 & 55.9 & 58.3 \\
Soluble solids (\%) (TSS) & Conserv II & 57.2 & 57.6 & 59.9 \\
& Wellwater & 12.0 & 11.7 & 11.2 \\
Acid (\%) (TA) & Conserv II & 10.9 & 11.5 & 10.5 \\
TSS:TA ratio & Wellwater & 0.88 & 0.84 & 0.86 \\
\multirow{3}{*}{ Soluble solids (kg/box) } & Conserv II & 0.80 & 0.80 & 0.77 \\
& Wellwater & 13.6 & 14.0 & 13.0 \\
& Conserv II & 13.6 & 14.4 & 13.8 \\
& Wellwater & 2.94 & 2.72 & 2.66 \\
\hline
\end{tabular}

FFrom Zekri and Koo (1990). Data were not analyzed statistically. 


\begin{tabular}{|c|c|c|c|c|c|c|}
\hline \multirow[b]{2}{*}{ Water } & \multicolumn{6}{|c|}{ Element (\% dry wt) } \\
\hline & $\mathbf{N}$ & $\mathbf{P}$ & K & $\mathrm{Ca}$ & $\mathrm{Mg}$ & $\mathrm{Na}$ \\
\hline $\begin{array}{l}\text { Wellwater } \\
\text { Reclaimed wastewatery }\end{array}$ & $\begin{array}{l}2.90 \pm 0.09 \\
2.96 \pm 0.06\end{array}$ & $\begin{array}{l}0.127 \pm 0.004 \\
0.139 \pm 0.004\end{array}$ & $\begin{array}{l}1.38 \pm 0.16 \\
1.41 \pm 0.10\end{array}$ & $\begin{array}{l}3.39 \pm 0.39 \\
3.27 \pm 0.23\end{array}$ & $\begin{array}{l}0.378 \pm 0.031 \\
0.379 \pm 0.025\end{array}$ & $\begin{array}{l}0.04 \pm 0.01 \\
0.09 \pm 0.02\end{array}$ \\
\hline
\end{tabular}

zFrom Zekri and Koo (1990). Leaf values are means of 1987, 1988, and 1989 data $\pm S D$.

$y 2.54 \mathrm{~cm} /$ week.

problem is that field personnel could come in contact with reclaimed irrigation water. However, since no bacteria or viruses are present in the efflux, the chance of health problems related to reclaimed water use are extremely small, unless there is a total breakdown of the treatment facility. This is highly unlikely because both facilities have emergency power and back-up systems.

\section{Conserv II}

Data have been and are being collected from young, nonbearing and mature 'Valencia', 'Hamlin', and 'Washington' navel orange trees on rough lemon or 'Carrizo' citrange rootstocksat 30 observation sites over a 1600 -ha planting under six different commercial management schemes (Koo and Zekri, 1989). All groves were fertilized based on current recommendations (Koo et al., 1984) and irrigated using microsprinklers or undercanopy, high-volume sprinklers. Nine sites received wellwater only and served as controls. Measurements included soil water content, tree size and yield, internal fruit quality [total soluble solids (TSS), titratable acidity (TA), TSS:TA, and juice content], and leaf nutrient analyses. Data have been collected since 1987; however, due to the size and nature of the study, data were not analyzed statistically.

Mature free growth and yields. Tree canopy appearance and leaf colorwere, in general, better for trees receiving reclaimed wastewater than for control untreated trees receiving wellwater (Zekri and Koo, 1990). Trees receiving reclaimed wastewater were deeper green in leaf color and in general more densely foliated. These ratings, however, were based on visual observations that differed only slightly numerically.

Yield data were not collected, but yield was estimated in 1988 (Koo and Zekri, 1989). Yields and both fruit size and number were greater for trees receiving reclaimed wastewater compared with wellwater. These data, along with grower observations, suggested $23 \%$ higher yields resulting from use of reclaimed wastewater. However, long-term yield data are needed to substantiate these figures.

Fruit quality differed in some years, but not others, for the two treatments (Table 2). Fruit from trees receiving reclaimed wastewater were larger and, in 2 years, had slightly higher juice content than fruit receiving wellwater. However, TSS and TA levels and kg-solids (a composite measure of TSS and juice content) were reduced due to the high levels of water applied in the reclaimed water treatment $(2.54 \mathrm{~cm} /$ week). Thus the TSS:TA ratio was slightly higher for the reclaimed water treatment, primarily due to the decrease in TA. These trends varied slightly among years because of differences in rainfall and soil water content, but were typical for citrus fruit from trees that receive high levels of irrigation.

Soil water content was greater for the reclaimed wastewater compared with the control at most times, but no evidence of water damage was observed in the well-drained sandy soils of the ridge. Weed growth was enhanced greatly in the reclaimed wastewater treatment vs. the control.

Leaf mineral content varied for some elements, but not others, related to water source (Table 3). Nitrogen levels were superoptimal but similar (Koo et al., 1984) for both treatments. Potassium, calcium, and magnesium levels were also similar. Leaf phosphorus and especially sodium levelswere higher in the reclaimed wastewater treatment, but sodium levels were below the toxic range (Embleton et al., 1973).

Young free growth and development. Irrigation with reclaimed wastewater significantly increased growth of 1- to 2-year-old citrus trees over the control (Koo and Zekri, 1989). Similarly, Parsons and Wheaton (1992) observed excellent young tree growth using high rates of reclaimed wastewater in the ridge area of Florida.

\section{Vero Beach}

Mature tree growth and yields. Data have been collected for only 1.5 years in the Vero Beach study. 'Redblush' and 'Marsh' grapefruit trees (20 to 25 years old) were used in this study with either sour orange or rough lemon as rootstocks. The experimental site is much smaller than the Conserv II site, but the study was set up as a completely randomized design and compared three application rates of reclaimed water (2.31, 3.07 , and $3.86 \mathrm{~cm} /$ week) with a control (canal water), which received water based on soil water deficit (Koo, 1963). Microsprinkler irrigation was used to apply the water. During the 1990-91 season, there were large differences in the amounts of water applied for each treatment (Table 4). The greatestamount of water was applied to the control during the spring quarter (April-June), with no water applied during the wetter-than-average summer quarter (July-September). Soil water content for all reclaimed water treatments was above field capacity for the entire season. Control beds were irrigated at one-third soil water depletion from January to June and at one-third depletion the rest of the year (Koo, 1963).

Tree vigor, monitored subjectively, and trunk circumference were unaffected by the treatments in the first year (Table 5). However, there was a substantial numerical increase in yields for all reclaimed water treatments over the controls in the same year (Table 6). This may have been due, in part, to water stress in the controls during January, which was drier than normal, warranting further long-term study. There were no differences in yields among the three reclaimed water rates, however.

The most surprising result from the Vero Beach study was the lack of effect of large quantities of water on grapefruit quality. Fruit samples were collected from Aug. 1990 until Mar.1991 (harvest). At no time did juice content, TSS, TA, or TSS:TA differ among treatments (February data only, Table 7). Fruit size, however, was smaller (data not shown) for controls compared to re-

Table 4. Total water applied by microirrigation to mature 'Redblush' grapefruit trees at Vero Beach, Fla., 1990-91.

\begin{tabular}{|c|c|c|c|c|c|}
\hline \multirow[b]{2}{*}{ Treatment } & \multicolumn{5}{|c|}{ Quarter ${ }^{2}$} \\
\hline & 1st & 2nd & 3rd & 4th & Total \\
\hline & \multicolumn{5}{|c|}{ Centimeters' } \\
\hline Canal water & 3.5 & 4.0 & 6.8 & 0.0 & 14.3 \\
\hline \multicolumn{6}{|c|}{$\begin{array}{l}\text { Reclaimed wastewater } \\
(\mathrm{cm} / \text { week })\end{array}$} \\
\hline 2.31 & 25.6 & 27.7 & 24.6 & 24.1 & 102.1 \\
\hline 3.07 & 29.7 & 35.3 & 30.5 & 32.3 & 127.8 \\
\hline 3.86 & 39.1 & 43.4 & 36.6 & 36.8 & 156.0 \\
\hline
\end{tabular}

zFirst quarter: October-December; second quarter: January-March; third quarter: April-June; fourth quarter: July-September.

y/rrigation was applied to 1.56 ha for each treatment. 
Table 5. Effects of reclaimed wastewater and canal water on growth of mature 'Redblush' grapefruit trees at Vero Beach, Fla., 1991.

\begin{tabular}{|c|c|c|c|c|}
\hline \multirow[b]{2}{*}{ Treatment } & \multicolumn{2}{|c|}{ Visual rating ${ }^{2}$} & \multicolumn{2}{|c|}{ Trunk cross-sectional area ${ }^{y}\left(\mathrm{~cm}^{2}\right.$} \\
\hline & 1990 & .1991 & 1990 & 1991 \\
\hline $\begin{array}{l}\text { Canal water } \\
\text { Reclaimed wastewater } \\
(\mathrm{cm} / \text { week })\end{array}$ & 4.9 & 4.7 & 132 & 137 \\
\hline 2.31 & 5.3 & 5.4 & 150 & 157 \\
\hline 3.07 & 5.7 & 5.9 & 160 & 165 \\
\hline 3.86 & 5.6 & 5.7 & 170 & 175 \\
\hline
\end{tabular}

"Visual ratings: $1=$ small, low vigor; $8=$ large, vigorous. $n=4$ beds (replications)/treatment, with 12 single tree samples/bed.

${ }^{y}$ Trunk cross-sectional area $n=4$ beds (replications)/treatment, with 12 single-tree samples/bed. There are no statistical differences among treatments for either year at the $5 \%$ level.
Table 6. Effects of reclaimed wastewater and canal water on yields of mature 'Redblush' grapefruit trees at Vero Beach, Fla., 1992.

\begin{tabular}{lc}
\hline Treatment & Yield $^{\mathbf{z}}$ (kg/tree) \\
\hline $\begin{array}{l}\text { Canal water } \\
\text { Reclaimed wastewater }\end{array}$ & 130.9 \\
(cm/week) & \\
2.31 & \\
3.07 & 208.0 \\
3.86 & 220.9 \\
& 188.0
\end{tabular}

zYield based on harvesting four beds (replicates)/ treatment. The yield for the entire bed was divided in Feb. 1992. There were no significant differences among treatments at the $5 \%$ level.

claimed wastewater treatments, again possibly related to water stress. The fruit size differences may have resulted in yield differences, but further data are needed to confirm this. The most likely TA was theexcessive rainfall during July and Aug. 1990, which equalized soil moisture content among the treatments; thus, the dilution effect was not as apparent as in a dry season. This lack of effect on fruit quality illustrates the need for long-term research over a wide range of climatic conditions.

Leaf mineral concentration was similar and relatively low for all treatments for nitrogen, phosphorus, and potassium, butwithin acceptable levels for calcium and magnesium (Table 8). These values were low because trees did not receive a summer fertilization due to excessive rainfall during July and August. Sodium and boron levels were higher for all reclaimed wastewater treatments than for controls. However, values were well below toxic levels (Embleton et al., 1973).

The most dramatic effect of applying large quantities of reclaimed wastewater to grapefruit in the Indian River area was enhanced weed growth. All reclaimed wastewater treatments had significantly greater weed growth within the tree row than the controls. Standard application of residual herbicides had to be modified to use more-expensive, less-soluble materials. Furthermore, additional postemergence spot treatments were needed to control weeds in all reclaimed wastewater treatby the number of trees/bed. Fruit were harvested reason for the lack of a dilution effect on TSS and ments. This is an important economic factor for growers to considerwhen deciding whether to use reclaimed wastewater for irrigation.

A major concern before beginning the project was that large quantities of reclaimed wastewater might not drain from the site, causing anaerobic soil conditions and root death. Citrus trees are quite sensitive to waterlogging, especially when soil temperatures are high during the summer. This, however, did not appear to be the case, as soil redox potentials remained above $300 \mathrm{mv}$ (aerobic conditions) at a $45-\mathrm{cm}$ depth for all but the most poorly drained areas, even during the rainy season. Therefore, drainage did not appear to be a problem during the first season. Moreover, no excessive leaching of nitrates or other elements were observed in water samples collected from the ditches between the beds.

Young free growth and development. Reclaimed wastewater treatments had no adverse effects on growth of newly planted trees at the Vero Beach site during the first season (data not shown). Similarly, studies from Gainesville conducted on ridge and flatwoods-type soils suggest that reclaimed wastewater alone does not provide sufficient nutrients for young tree growth during the first three seasons, and that high irrigation rates (127cm/year) do not increase tree growth over that of trees receiving recommended irrigation levels (Maurer and Davies, 1992).

\section{Conclusions}

Irrigation of young and mature citrus trees using reclaimed municipal wastewater has great potential for efficiently distributing reclaimed wastewater while providing irrigation in both the ridge and flatwoods areas of Florida. Preliminary data suggest that high application rates of high-quality reclaimed wastewater is not harmful to citrus and may improve fruit size and yields and also decrease fertilizer levels. However, these high application rates may decrease TSS and TA of the juice and increase weed pressures and costs of weed control. More long-term data are needed to confirm these observations, particularly for groves in the flatwoods areas of Florida. Nevertheless, application of reclaimed wastewater to citrus groves
Table 7. Effects of reclaimed wastewater and canal water on fruit quality of mature 'Redblush' grapefruit trees at Vero Beach, Fla., 1992.

\begin{tabular}{lcccc}
\hline & \multicolumn{4}{c}{ Fruit quality factors $^{2}$} \\
\cline { 2 - 5 } Treatment & Juice (\%) & TSS (\%) & TA (\%) & TSS:TA \\
\hline $\begin{array}{l}\text { Canal water } \\
\text { Reclaimed wastewater }\end{array}$ & 59.8 & 11.4 & 1.11 & 10.3 \\
$\begin{array}{l}(\mathrm{cm} / \text { week) } \\
2.31\end{array}$ & & & & \\
3.07 & 61.6 & 11.2 & 1.10 & 10.2 \\
3.86 & 61.6 & 11.0 & 1.09 & 10.2 \\
& 60.6 & 11.1 & 1.07 & 10.4
\end{tabular}

${ }^{2}$ Ten fruit samples were collected from three trees from each of four beds (replicates)/treatment. Fruit were harvested in Feb. 1992. TSS = total soluble solids, TA=titratable acid. There were no significant differences among treatments at the $5 \%$ level.

Table 8. Effects of reclaimed wastewater and canal water on leaf mineral content of mature 'Redblush' grapefruit trees at Vero Beach, Fla., 1991.'

\begin{tabular}{|c|c|c|c|c|c|c|c|}
\hline \multirow[b]{2}{*}{ Treatment } & \multicolumn{7}{|c|}{ Element } \\
\hline & $\mathbf{N}$ & $\mathbf{P}$ & K & $\begin{array}{c}\mathrm{Ca} \\
\text { (\% dry wt) }\end{array}$ & $\mathrm{Mg}$ & $\mathrm{Na}$ & $\frac{B}{\frac{B}{\left(m g \circ g^{-1} \text { dry wt) }\right.}}$ \\
\hline $\begin{array}{l}\text { Canal water } \\
\text { Reclaimed } \\
\text { wastewater } \\
\text { (cm/week) }\end{array}$ & 1.8 & 0.09 & 0.71 & 5.4 & 0.49 & 0.068 & 77 \\
\hline 2.31 & 1.8 & 0.09 & 0.80 & 5.3 & 0.48 & 0.076 & 116 \\
\hline 3.07 & 1.8 & 0.09 & 0.73 & 5.3 & 0.47 & 0.073 & 132 \\
\hline 3.86 & 1.8 & 0.09 & 0.80 & 5.4 & 0.45 & 0.079 & 116 \\
\hline
\end{tabular}

${ }^{2}$ Mean of 50 spring-flush leaves/bed collected from four beds (replicates)/treatment in Sept. 1991. There were no significant differences among treatments at the $5 \%$ level. 
could be mutually beneficial by providing an outlet for reclaimed municipal wastewater, and to citrus growers by providing low-cost, reliable irrigation.

\section{Literature Cited}

Davies, F.S. and L.K. Jackson. 1985, Methods of cold protection for young citrus. Univ. of Florida, Gainesville. Fruit Crops Dept. Fact Sheet 75.

Embleton, T.W, W.W. Jones, C.K. Labanauskas, and W. Reuther. 1973. Leaf analysis as a diagnostic tool and guide to fertilization, p. 183-210. In: W. Reuther (ed.). The citrus industry. vol. 3. Univ. of California Press, Berkeley.

Florida Dept. of Agr. and Consumer Serv. 1990. Citrus summary. Florida Agr. Stat., Orlando.

Koo, R.C.J. 1963. Effects of frequency of irrigation on yield of orange and grapefruit. Proc Fla. State Hort. Soc. 76:1-5.

Koo, R.C.J., I. Stewart, D.P.H. Tucker, D.V. Calvert, and H.K Wutscher. 1984. Recommended fertilizers and nutritional sprays for citrus. Univ. of Florida. Bul. 536D.

Koo, R.C.J. and M. Zekri 1989. Citrus irrigation with reclaimed municipal wastewater. Proc. Fla. State Hort. Soc. 102:52-56.

Mauer, M. and F.S. Davies. 1992. Reclaimed water and microsprinkler irrigation of one- and twoyear-old grapefruit trees. HortScience 27:604. (Abstr.)

McMahon, B.R., R.C.J. Koo, and H.W. Persons. 1989. Citrus irrigation with reclaimed wastewater. Trans. Citrus Eng. Conf. 35:1-17.

Overman, A.R., L.R. Totora, and T. Schanze. 1987. Agricultural reuse of reclaimed water. Amer. Soc. Agr. Eng. Microfiche Collection 87-2634.

Parsons, L.R. and T.A. Wheaton. 1992. Effects of irrigation rate with reclaimed water on growth and leaf mineral content of young citrus trees. HortScience 27:603. (Abstr.)

Servis, R. 1991. TEW Groves Inc. is first wastewater irrigation for citrus in Pasco County. Citrus Ind. May, p. 42.

Smajstrla, A.G., D.S. Harrison, D.Z Haman, and F.S. Zazueta. 1992. Irrigated acreage in Florida. Florida Coop. Ext. Serv. Circ. 1030. Univ. of Florida Press, Gainesville.

Zekri, M. and R.C.J. Koo. 1990. Effects of reclaimed wastewater on leaf and soil mineral composition and fruit quality of citrus. Proc. Fla. State Hort. Soc. 103:38-41.

HortTechnology · Apr./June 1993 3(2) 